Perspective, part of a Special Feature on The Energy-Water Nexus

\title{
The Penobscot River, Maine, USA: a Basin-Scale Approach to Balancing Power Generation and Ecosystem Restoration
}

\author{
$\underline{\text { Jeffrey J. Opperman }}^{1}, \underline{\text { Joshua Royte }}^{1}, \underline{\text { John Banks }}^{2}, \underline{\text { Laura Rose Day }}^{3}$, and Colin Apse $^{1}$
}

\begin{abstract}
Although hydropower is a source of low-carbon energy, without careful consideration and management, dams have the potential to degrade river ecosystems and the goods and services they provide to society. Today, a broad range of hydropower interests and stakeholders are seeking approaches to hydropower development and operation that are more environmentally and socially sustainable. The Penobscot River Restoration Project ('the Project') illustrates that basin-scale approaches can provide a broader set of solutions for balancing energy and riverine environmental resources than can be achieved at the scale of individual projects. The Penobscot basin is the largest in Maine and historically supported culturally and economically significant populations of migratory fish. These migratory fish populations declined dramatically following the construction of a series of hydropower dams on the main stem river and major tributaries in the early 20th century. The Project, negotiated between a power company (PPL Corporation) and a coalition including the Penobscot Indian Nation, resource agencies, and nongovernmental conservation organizations, features the removal of two main stem dams on the lower Penobscot and improved fish passage at the dams that remain. Because of various capacity and/or operational changes, power production will be increased at the remaining dams and total hydropower energy production from the basin will be maintained or increase slightly. The Project is expected to expand considerably the proportion of the basin accessible to migratory fish and contribute to significant increases in fish populations. The Project illustrates that a basin-scale approach can potentially yield more comprehensive solutions for sustainable hydropower than can be achieved at the project scale, and we recommend that such large-scale planning processes can improve the sustainability of both regulatory licensing of existing dams as well as the planning of future dams in regions undergoing the expansion of water-management infrastructure.
\end{abstract}

Key Words: Atlantic salmon; dam removal; hydropower; river restoration

\section{INTRODUCTION}

Hydropower poses one of today's more complex environmental challenges: although hydropower dams generally produce low-carbon energy they can also disrupt river ecosystems and diminish or eliminate the numerous important societal and ecological benefits provided by free-flowing, healthy rivers (Postel and Richter 2003). Without careful consideration and management, dams can negatively impact downstream ecosystems by altering flow regimes, degrading water quality, obstructing and/or delaying fish passage, and eliminating critical spawning and rearing habitat for migratory species (Ligon et al. 1995, Bunn and Arthington 2002), and these losses in ecosystem functions and services can have significant social costs, such as the loss of important fisheries (Dudgeon 2000). Increasingly, hydropower interests and stakeholders recognize that the sector must operate and develop in a manner that minimizes its social and environmental impacts (World Commission on Dams 2000, IHA 2004). Although improving the operations of individual dams can achieve significant environmental improvements (Richter and Thomas 2007), we emphasize the importance of basin-scale, multidam approaches for achieving more sustainable hydropower, defined as hydropower production systems that are consistent with the maintenance of a region's riverine biodiversity and ecosystem services. 
Achieving the objective of more sustainable hydropower operation and development will require advances in technology, engineering, river science, planning, and policy. These advances need to be tested, demonstrated, refined, and communicated through effective case studies. We describe the Penobscot River Restoration Project ('the Project') in Maine, USA to illustrate a basin-scale approach to improving hydropower sustainability.

In this paper we describe the Project, the context in which it emerged, and key elements of the solutions it achieved, including projected implications for fish habitat and energy production. The Project clearly demonstrates the scope of benefits, for both energy and ecosystems, that are possible through basinscale approaches to sustainable hydropower. We conclude by reviewing insights from the Project that can be applied more generally toward the pursuit of sustainable hydropower, including the regulatory structure governing existing dams as well as the planning, siting, and development of new hydropower dams in regions of the world undergoing expansion of water and energy infrastructure.

\section{GEOGRAPHY, RESOURCES, CULTURE, AND HISTORY OF PENOBSCOT RIVER}

The Penobscot River basin (2.2 million hectares), the largest in Maine and second largest in the Northeastern United States of America, encompasses over $8800 \mathrm{~km}$ of main stem and mapped tributary habitat (Fig. 1). The basin is predominately forested ( $95 \%$ forest cover) with a wet climate $(104 \mathrm{~cm} /$ year of precipitation; NOAA 1998), yielding the Penobscot's average annual discharge of $465 \mathrm{~m}^{3} / \mathrm{s}$ (Penobscot Department of Natural Resources 2001). The Penobscot is a primary source of freshwater for the Gulf of Maine, one of the largest estuaries in Maine and the U.S. East coast.

Archeological evidence indicates that the Wabanaki people, four tribes that include the present-day Penobscot, began living in the Penobscot River valley at least 9000 years ago and continuously occupied the region through precontact times (Sanger et al. 1992). Prior to European contact, the Wabanaki depended on the Penobscot valley's natural resources through hunting, gathering, and fishing. An early written account noted that in the 1790 s "game was found in great abundance along the banks of this river...[striped] bass were plenty in the Penobscot, and sturgeon, [which] were esteemed of not value for food, made havoc with the seines of fishermen" (described in Williams, Chase \& Co. 1882:539). Large populations of diadromous fish, those that migrate between salt and freshwater to complete their life cycle, were ecologically, culturally, and economically important, including alewife (Alosa pseudoharengus), American shad (Alosa sapidissima), blueback herring (Alosa aestivalis), Atlantic salmon (Salmo salar), sea lamprey (Petromyzon marinus), American eel (Anguilla rostrata), rainbow smelt (Osmerus mordax), Atlantic tomcod (Microgadus tomcod), striped bass (Morone saxatilis), sea-run brook trout (Salvelinus fontinalis), Atlantic sturgeon (Acipenser oxyrinchus), and shortnose sturgeon (Acipenser brevirostrum; Table 1). Historical accounts indicate that American shad supported the most economically valuable fishery with annual runs of over two million fish, followed by Atlantic salmon with runs prior to 1830 exceeding 100,000 fish (Atkins and Foster 1869). The ranges of the Penobscot's diadromous (hereafter "migratory") fish varied, with the sturgeon, smelt, tomcod, and sea-run brook trout all likely restricted by the natural fall line, where Milford Dam is currently located (Fig. 1). Other species migrated significantly further upstream to the many headwater streams that lacked impassable waterfalls (Table 1; Saunders et al. 2006, Maine Department of Marine Resources 2009).

European exploration and early settlement of the valley began in the 16th century. Commercial fishing expanded alongside the development of the towns of Bangor and Bucksport in the 1760s. In the early 19 th century, industrial development began to impact the migratory fish populations and the people and wildlife dependent upon them. Starting in the 1820s, dams were constructed on the Penobscot main stem just above head of tide and in the current locations of the Veazie, Great Works, and Milford dams (Fig. 1, Table 2), blocking passage to migratory fish spawning and rearing grounds. These impacts were apparent the first year after the closure of Veazie dam as "a great many shad and alewives lingered about the dam and died there, until the air was loaded with the stench" (Atkins and Foster 1869).

Other portions of the river were also heavily impacted by overfishing and fragmentation; by 1837 more than 250 saw mills, each with a milldam, were active along the Penobscot and its tributaries 
Fig. 1. Map of Penobscot basin.

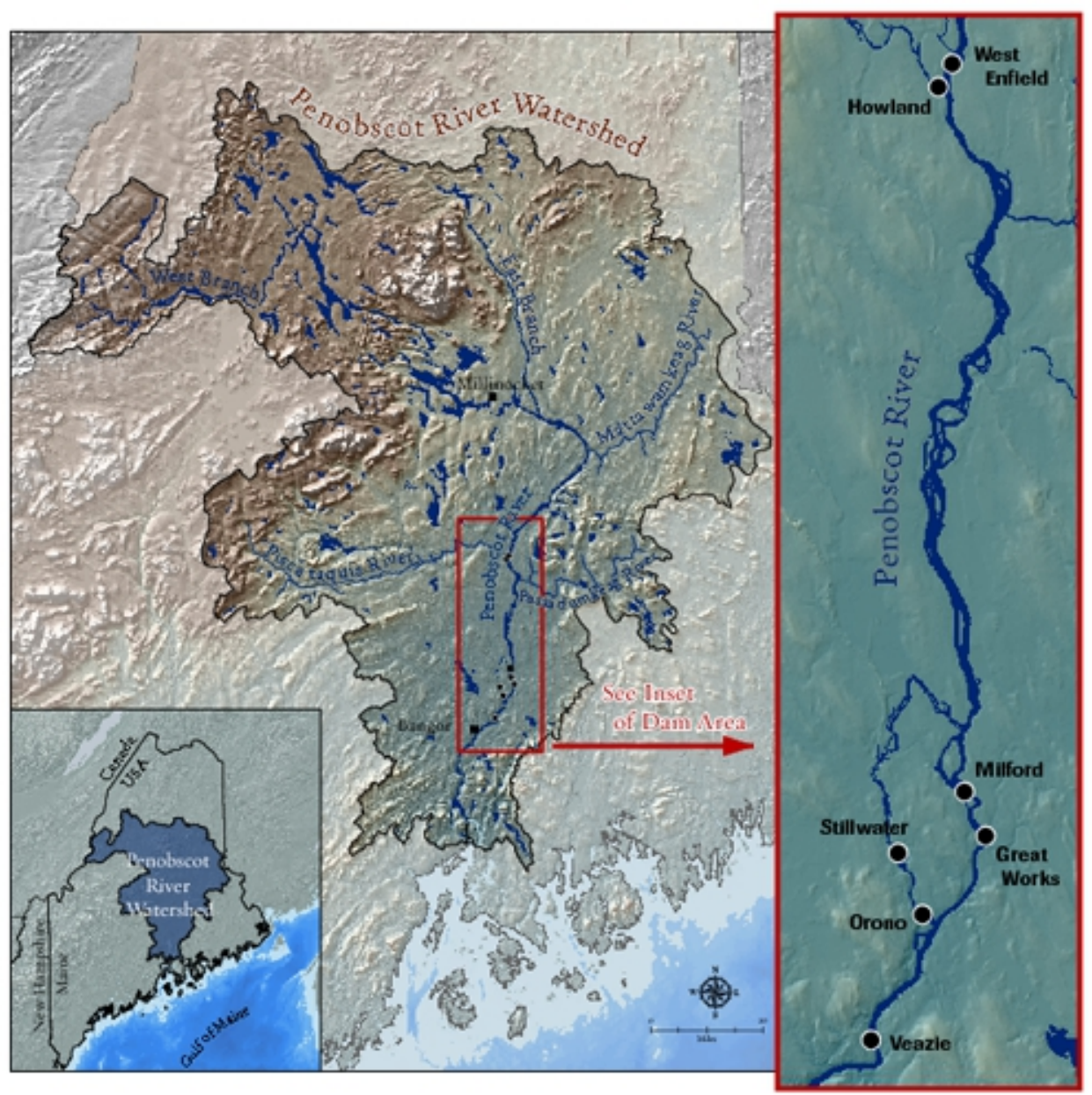

(Atkins and Foster 1869). Laws to promote fishways, i.e., fish passage, on these milldams proved ineffective, particularly for American shad, and the Penobscot experienced a rapid decline in migratory fish populations reflecting broader trends across New England (Montgomery 2003). By 1868 the Penobscot's population of American shad was reduced to approximately 5000 (Atkins and Foster 1869) and "by 1908, salmon were so rare in portions of the Penobscot River that newspapers reported when one was caught" (Montgomery 2003:110). The dramatic decline of migratory fish populations had significant cultural and economic impacts, particularly on the Penobscot Indian Nation (Robinson et al. 2009).

The water quality of the Penobscot River continued to decline in the 20th century because of discharges from tanneries, three large pulp and paper factories, and municipal wastewater outfalls (FERC 1997). Most toxic inputs to the river ecosystem, e.g., dioxin, mercury, DDT, and chlorine compounds, have declined over the past 40 years since the adoption of the federal Clean Water Act. Despite water quality improvements, current stocks of most migratory fish on the Penobscot are at or near historic lows and commercial fisheries have long since shut down (Saunders et al. 2006, Maine Department of Marine Resources 2009). The most recent recognition of this decline was the 2009 listing of the Penobscot River population of Atlantic salmon, the largest run left in the United States, under the federal Endangered Species Act (NOAA 2009). The loss of access to habitat due to dams was the primary cause cited for the decline of the river's salmon (NRC 2004). In 2004, the National Research 
Table 1. Migratory fish in the Penobscot basin, including original range of migration, current range, and projected range after Project completion.

\begin{tabular}{|c|c|c|c|}
\hline Species & Original Range & Current Range & Expected Future Range \\
\hline $\begin{array}{l}\text { Alewife } \\
\text { (Alosa pseudoharengus) }\end{array}$ & $\begin{array}{l}\text { In ponds throughout most of } \\
\text { basin }\end{array}$ & No ponds above Milford & $\begin{array}{l}\text { Improved access to } 34 \text { ponds } \\
\text { above Veazie and more through } \\
\text { independent restoration projects } \\
\text { ( } 34 \% \text { of historic habitat) }\end{array}$ \\
\hline $\begin{array}{l}\text { American Eel } \\
(\text { Anguilla rostrata) }\end{array}$ & Throughout basin $(11,569 \mathrm{~km})$ & $\begin{array}{l}\text { Limited population } \\
\text { throughout basin }\end{array}$ & $\begin{array}{l}\text { Improved access to } 5148 \mathrm{~km} \text { for a } \\
\text { total of } 6893 \mathrm{~km}^{\dagger}(60 \% \text { of historic) }\end{array}$ \\
\hline $\begin{array}{l}\text { American Shad } \\
\text { (Alosa sapidissima) }\end{array}$ & $\begin{array}{l}\text { All major tributaries north to } \\
\text { Wassataquiok }(786 \mathrm{~km})\end{array}$ & To Milford only (62 km) & $\begin{array}{l}\text { Improved access to } 529 \mathrm{~km} \text { for a } \\
\text { total of } 690 \mathrm{~km}^{\dagger}(88 \% \text { of historic } \\
\text { range) }\end{array}$ \\
\hline $\begin{array}{l}\text { Atlantic Salmon } \\
\text { (Salmo salar) }\end{array}$ & Throughout basin $(11,569 \mathrm{~km})$ & $\begin{array}{l}\text { Limited populations } \\
\text { throughout basin (stocked } \\
\text { and trucked upstream of } \\
\text { Veazie) }\end{array}$ & $\begin{array}{l}\text { Improved access to } 5148 \mathrm{~km} \text { for a } \\
\text { total of } 6893 \mathrm{~km}^{\dagger} \text { ( } 60 \% \text { of historic } \\
\text { range) }\end{array}$ \\
\hline $\begin{array}{l}\text { Atlantic Sturgeon } \\
\text { (Acipenser oxyrinchus) }\end{array}$ & To Milford/Fall line $(62 \mathrm{~km})$ & To Veazie only (50 km) & To Milford/Fall line (62 km) \\
\hline $\begin{array}{l}\text { Atlantic Tomcod } \\
\text { (Microgadus tomcod) }\end{array}$ & Great Works & To Veazie only (50 km) & Great Works $(60 \mathrm{~km})$ \\
\hline $\begin{array}{l}\text { Blueback Herring } \\
\text { (Alosa aestivalis) }\end{array}$ & $\begin{array}{l}\text { All major tributaries north to } \\
\text { Wassataquiok }\end{array}$ & To Milford only (62km) & $\begin{array}{l}\text { Improved access to } 529 \mathrm{~km} \text { for a } \\
\text { total of } 690 \mathrm{~km}(88 \% \text { of historic } \\
\text { range) }\end{array}$ \\
\hline $\begin{array}{l}\text { Rainbow Smelt } \\
\text { (Osmerus mordax) }\end{array}$ & To Milford/Fall line (62 km) & To Veazie only (50 km) & $\begin{array}{l}\text { To Milford/Fall line, occasionally } \\
\text { above }(62 \mathrm{~km})\end{array}$ \\
\hline $\begin{array}{l}\text { Sea Lamprey } \\
\text { (Petromyzon marinus) }\end{array}$ & Throughout basin $(11,569 \mathrm{~km})$ & $\begin{array}{l}\text { Limited population } \\
\text { throughout basin }\end{array}$ & $\begin{array}{l}\text { Improved access to } 5148 \mathrm{~km} \text { for a } \\
\text { total of } 6893 \mathrm{~km}^{\dagger}(60 \% \text { of historic } \\
\text { range }\end{array}$ \\
\hline $\begin{array}{l}\text { Sea-Run Brook Trout } \\
\text { (Salvelinus fontinalis) }\end{array}$ & $\begin{array}{l}\text { Lower tributaries up to } \\
\text { Howland }(226 \mathrm{~km})\end{array}$ & $\begin{array}{l}\text { Tributaries below Veazie } \\
\text { only }(137 \mathrm{~km})\end{array}$ & $\begin{array}{l}\text { Tributaries below Howland ( } 226 \\
\mathrm{~km})\end{array}$ \\
\hline $\begin{array}{l}\text { Shortnose Sturgeon } \\
\text { (Acipenser } \\
\text { brevirostrum) }\end{array}$ & To Milford/Fall line (62 km) & To Veazie only $(50 \mathrm{~km})$ & To Milford/Fall line (62 km) \\
\hline $\begin{array}{l}\text { Striped Bass } \\
\text { (Morone saxatilis) }\end{array}$ & $\begin{array}{l}\text { To Milford/Fall line, } \\
\text { occasionally above }(62 \mathrm{~km})\end{array}$ & To Veazie only (50 km) & $\begin{array}{l}\text { To Milford/Fall line, occasionally } \\
\text { above }(62 \mathrm{~km})\end{array}$ \\
\hline
\end{tabular}

†assumes successful upstream passage through up to three fishways or successful downstream passage over up to three dams (additional habitat is accessible above four to five dams, but not included here). $\mathrm{T}$. Trinko, NOAA Fisheries, unpublished data. 
Table 2. Dams on the lower main stem of the Penobscot River.

\begin{tabular}{|c|c|c|c|c|c|c|}
\hline \multirow[b]{2}{*}{ Dam } & \multirow[b]{2}{*}{$\underset{(m)}{\text { Dam Height }}$} & \multirow[b]{2}{*}{$\begin{array}{l}\text { Dam } \\
\text { Length } \\
(\mathrm{m})\end{array}$} & \multirow[b]{2}{*}{$\begin{array}{l}\text { Hydropower } \\
\text { capacity (Mw) }\end{array}$} & \multirow[b]{2}{*}{$\begin{array}{l}\text { Distance to } \\
\text { Ocean }(\mathrm{km})\end{array}$} & \multicolumn{2}{|c|}{ Project Action } \\
\hline & & & & & $\begin{array}{l}\text { Proposed Action for } \\
\text { Fish }\end{array}$ & $\begin{array}{l}\text { Proposed Action } \\
\text { for Power }\end{array}$ \\
\hline Veazie & 6 & 327 & 8.4 & 55 & Removal & Offline \\
\hline Great Works & 6 & 435 & 7.7 & 69 & Removal & Offline \\
\hline Milford & 6 & 427 & 6.4 & 73 & $\begin{array}{l}\text { State-of-the-art fish } \\
\text { passage under } \\
\text { construction }\end{array}$ & Increase \\
\hline West Enfield & 7 & 296 & 13.0 & 114 & $\begin{array}{l}\text { Fish passage exists } \\
\text { (vertical slot fish } \\
\text { ladder) }\end{array}$ & Increase \\
\hline Medway & 11 & 541 & 19.2 & 175 & Future & Increase \\
\hline Orono & 8 & 343 & 2.3 & 63 & Future & New Power \\
\hline Stillwater & 6 & 539 & 1.9 & 67 & Future & Increase \\
\hline Howland & 6 & 201 & 1.9 & 112 & Bypass & Offline \\
\hline
\end{tabular}

Council of the National Academies of Science recommended that the Penobscot should be the top priority in the U.S. for the recovery of wild Atlantic salmon and that dam removal was necessary for achieving recovery (NRC 2004).

\section{REGULATORY CONTEXT FOR PENOBSCOT RIVER RESTORATION PROJECT}

Dams on the Penobscot, and nearly all nonfederal hydropower dams in the United States, are regulated by the Federal Energy Regulatory Commission (FERC or 'the Commission'), created by the Federal Power Act (FPA; 1920 and 1935). FERC issues 30to 50-year licenses to hydropower projects; projects must undergo a relicensing process prior to license expiration. Previous licensing and relicensing (collectively, "licensing") of hydropower dams on the Penobscot created the context in which the Project emerged. In this section we review FERC regulations and provide a brief summary of licensing processes that set the stage for the Project.
An amendment to Section 4(e) of the FPA, the Electric Consumers Protection Act of 1986(ECPA), required FERC to give "equal consideration" to conservation and recreational uses of rivers alongside hydropower production. Through ECPA Congress directed FERC to provide a greater balance within licensing processes between energy production and recreational and environmental resources (Gillilan and Brown 1997). Because of ECPA and other provisions, relicensing provides an opportunity to periodically reassess the relative benefits and impacts of hydropower projects and to ensure that projects comply with new legislation, e. g., the Clean Water Act (CWA) and Endangered Species Act (ESA), that have come into force since the previous license was issued (Echeverria et al. 1989).

During licensing processes, federal resource and regulatory agencies can exercise "conditioning authority" under which they issue conditions that FERC must incorporate into a license. State agencies that implement the Federal CWA can also exert conditioning authority (Pollak 2007). This 
conditioning authority can include the ability of federal agencies to require fish passage at dams and FERC has asserted the right to require a dam to be removed if it is in the public interest, with the prominent example of Edwards Dam on the Kennebec River in Maine (Bowman 2002).

FERC licensing has undergone several procedural changes and projects now generally pursue a new license through the Integrated Licensing Process (ILP), which strives to more effectively incorporate state and federal agencies and stakeholders, such as conservation and recreational NGOs, into the relicensing process. Through the ILP, FERC now encourages relicensing processes to culminate in settlement agreements, legally binding agreements that are negotiated and signed by a licensee and signatories such as tribal nations, state and federal agencies, and NGOs. A settlement agreement describes in detail the terms for the license, including components such as dam operations, flow regime, and environmental mitigation (Hydropower Reform Coalition 2005).

Several factors facilitated a comprehensive approach to hydropower licensing on the Penobscot that included system-wide fish-passage improvements. We briefly review these factors and the chronology of licensing processes along the river to demonstrate how they shaped the regulatory, environmental, social, and political context from which the Project emerged.

First, in the late 20th century, dam relicensing and proposals to license new dams on the Penobscot often led to divisive processes, illustrating the potential expense and conflict that could accompany the licensing of an individual project. In the early 1980s, the Swift River Company proposed to install hydropower turbines and rehabilitate the degraded Bangor Dam. This proposal galvanized intense resistance from the angling community and FERC denied the license. The dam deteriorated and was eventually removed. In the late $1980 \mathrm{~s}$, BangorHydro, which at that time owned most of the hydropower dams on the lower Penobscot River, proposed to build Basin Mills, a new 38 megawatt (MW) dam at the confluence of the Penobscot main stem and the Stillwater, a major side channel of the Penobscot. Multiple stakeholders participated in a lengthy licensing process that highlighted increasing tensions between hydropower development, tribal jurisdiction, fisheries and recreation, and, in 1998, FERC denied the license. However, through these same proceedings, FERC issued new licenses for the Veazie and Milford dams. The Basin Mills decision left most parties dissatisfied, prompting appeals by all parties on several key issues, and it was generally understood that fish passage would continue to be a major issue for subsequent licensing processes.

A second factor facilitating a basin-scale approach to licensing was the consolidation of all the hydropower projects on the lower Penobscot under a single owner. In 1998, following electricity deregulation, Bangor-Hydro elected to retain its transmission assets while divesting its generating assets. In 1999, PPL Corporation purchased all of Bangor-Hydro's hydropower projects in the Penobscot basin, including, the Veazie, Milford, Howland, West Enfield, Medway, Orono, and Stillwater dams (Table 2). PPL's purchase of Great Works dam from Ft. James in 2000 resulted in PPL Corporation's sole ownership of the lower Penobscot dams.

A third important factor that facilitated a comprehensive approach was the legal status of the Penobscot Indian Nation ('the Tribe'). The Tribe's status as a Federally Recognized Sovereign Indian Tribe, reaffirmed by the Maine Indian Land Claims Act of 1980, requires the federal government to exercise its "trust responsibility" to ensure proper management and protection of tribal natural resources, such as the right to harvest fish within the waters of the reservation. The FPA requires FERC to consult with the U.S. Department of the Interior ('Interior') when a licensing decision may impact tribal trust resources. Because the hydropower dams on the lower Penobscot clearly affected fishing access, the Tribe, through Interior, advocated for restoration of adequate fish runs during licensing processes. Additionally, during the Milford licensing, the Tribe engaged in a legal dispute with the state of Maine and hydropower interests over whether the Tribe should be considered a federal "reservation." Under Section 4(e) of the FPA, FERC must ensure that licensed projects do not interfere with the purposes of any federal reservation, defined to include national forests, military bases, and Native American Reservations. During licensing, Interior can exercise prescriptive authority to protect the purposes for which a reservation exists, e.g., such as fishing rights (Echeverria et al. 1989). This dispute loomed as a major issue confronting any subsequent licensing processes. 
When consolidation of ownership created an opportunity to address hydropower and fish passage in a comprehensive manner, the parties agreed to set aside the dispute over FPA-reservation status with each government maintaining their respective legal positions. This removed a potential legal obstacle to comprehensive licensing and fish restoration.

\section{PENOBSCOT RIVER RESTORATION PROJECT}

The possibility of a comprehensive approach to hydropower licensing and fish passage restoration was facilitated by the tabling of the dispute over FPA-reservation status, the specter of contentious battles over fish passage for individual relicensing processes, and the consolidated ownership of the lower Penobscot dams under one company willing to consider alternative approaches. In 1999, PPL and the Tribe initiated discussions, subsequently joined by conservation groups, and state and federal agencies, focused on potential alternatives to siteby-site licensing processes that could more effectively balance hydropower production and fisheries restoration.

A diverse set of parties discussed and negotiated the major issues, including PPL Corporation, the Penobscot Indian Nation, the State of Maine, the Department of the Interior (Bureau of Indian Affairs, U.S. Fish and Wildlife Service, National Park Service), and five nonprofit conservation organizations (American Rivers, Atlantic Salmon Federation, Maine Audubon, Natural Resources Council of Maine, and Trout Unlimited). In October 2003, the parties announced that they had reached a conceptual agreement that outlined the principles for rebalancing fisheries restoration and hydropower production on the lower river. For several months, the parties solicited further input on their proposal through a series of public meetings attended by citizens, organizations, and businesses in the region.

In 2004, the parties filed with FERC the Lower Penobscot River Comprehensive Settlement Accord (FERC 2004), a multiparty legal agreement designed to reconfigure hydropower production on the lower Penobscot system to both restore migratory fish populations while maintaining hydropower production under new licenses at PPL's dams (Table 2). Under the agreement, PPL granted a five-year option to purchase three dams (Veazie, Great Works, and Howland; Fig. 1) to the newly created not-for-profit Penobscot River Restoration Trust ('the Trust') for between US\$24 million and US\$26 million. The Trust is composed of the Penobscot Indian Nation and the five conservation NGOs involved in the negotiation; The Nature Conservancy joined the Trust as a sixth conservation NGO in 2006.

Upon receipt of required permits, the Trust will decommission the power plants of all three dams, remove the two most seaward dams (Veazie and Great Works; Fig. 2), and construct a fish bypass around the third dam, Howland, which is located on the Piscataquis River just $150 \mathrm{~m}$ from its confluence with the Penobscot River (Fig. 1). The bypass fishway at Howland will be able to accommodate a broad range of flow conditions and its slope (1.5\%) is sufficiently low such that relatively poorswimming species like American shad can use it to reach upstream spawning grounds (Fig. 3; FERC 2010). The dam at Howland will remain because the local community prefers the water elevations created by the reservoir. As part of the Settlement Accord, PPL is required to improve fish passage at four other Penobscot dams, i.e., Stillwater, Orono, Medway, and Milford.

Milford Dam, currently the third dam upstream from the ocean, was not acquired by the Trust and will continue to generate hydropower. After completion of the decommissioning of the two lowermost dams, scheduled to begin in summer 2012 or summer 2013, Milford will be the first dam upstream from the Gulf and the only one remaining on the lower main stem of the Penobscot River (Fig. 1). PPL Corporation will improve fish passage at the Milford Dam beyond that required in their current license through construction of a state-of-the-art fish lift.

Finally, the Accord provides PPL with new licenses for their remaining six dams in the Penobscot basin, including the right to increase hydropower generation at these dams to maintain total basin energy generation at current levels (Fig. 4). The project-level increases in generation will be achieved through repowering Orono Dam, on the Stillwater Branch of the Penobscot, which is parallel to the main channel (Fig. 1), and adding an additional foot of head on three impoundments (Table 2). Because of these improvements, PPL Corporation projects a slight increase in energy production after project completion (Scott Hall, PPL Corp., personal communication). 
Fig. 2. A visualization of dam removal (Veazie Dam) that was used for public outreach and fundraising (images provided by MMI Engineering courtesy of the Penobscot River Restoration Trust).
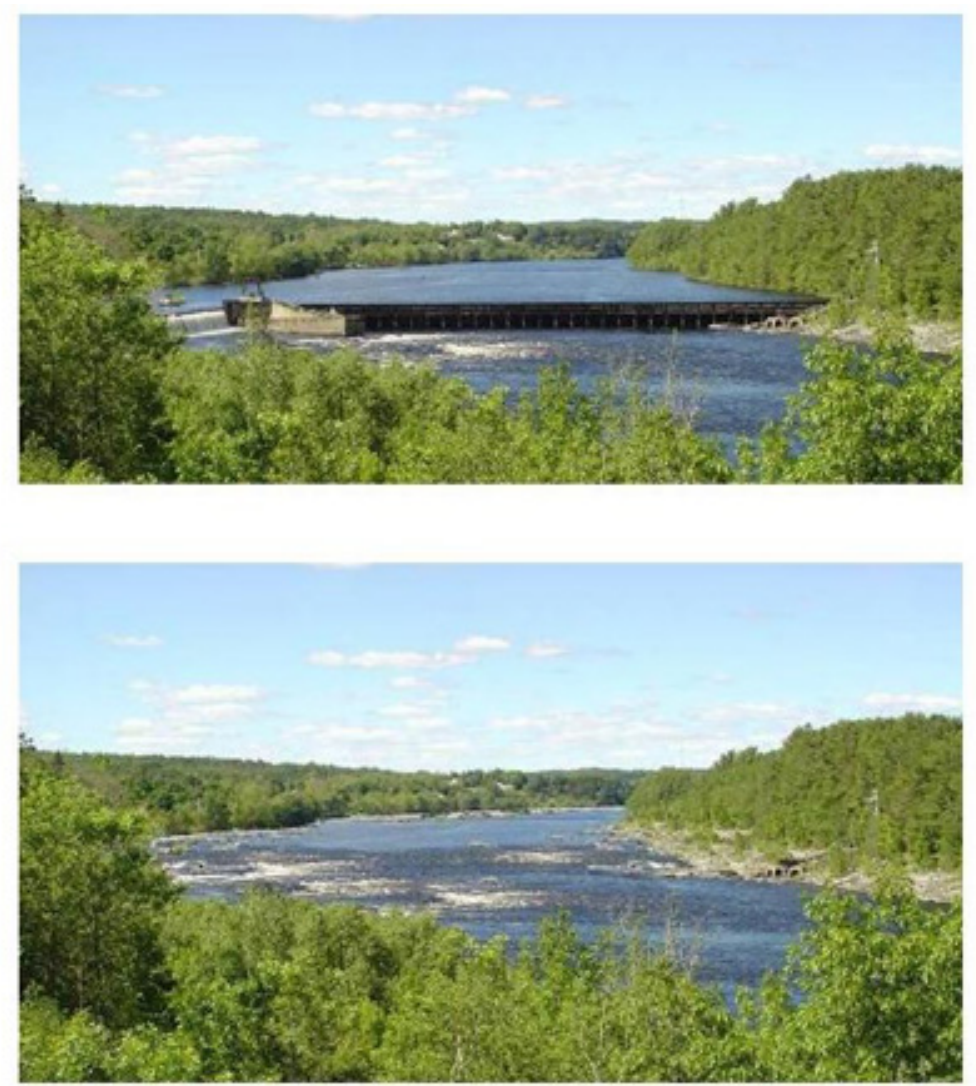

Once the Veazie and Great Works dams are removed and the Howland bypass is constructed, the extent of free-flowing river habitat and overall connectivity in the basin will both increase considerably. Through the removal of Veazie and Great Works dams alone, the project will restore essentially all historic habitat for federally endangered shortnose sturgeon, tomcod, striped bass, rainbow smelt, and Atlantic sturgeon (Saunders et al. 2006). With fish passage improvements at Milford and Howland, the six long-distance migrants (alewife, blueback herring, American shad, American eel, sea lamprey, and Atlantic salmon) will have access to as much as twothirds of their historic habitat in this watershed (Table 1).

The actual increases in fish habitat for long-distance migrants will be strongly influenced by the species- specific effectiveness of the fish passage. Even effective fish passage facilities inflict some attrition on migrating fish populations because of exhaustion, increased risk of predation, or failure to find or surmount the passage structure. Projections of habitat increases and associated fish recovery for the Project assume that populations of certain fish such as American shad and Atlantic salmon can withstand the attrition associated with passing a maximum of three dams. For the purposes of estimating biological benefits, reaches upstream of a fourth dam are thus considered significantly less accessible because the cumulative losses render those reaches much less likely to support viable populations of these species. Using Atlantic salmon as an example, approximately $480 \mathrm{~km}$ of historic salmon spawning and rearing habitat in the Penobscot are currently accessible by passage over three or fewer dams with passage facilities. 
Fig. 3. The design for the fish bypass at Howland Dam, seen in photo. The Red arrows point to the same structure in each image. In the lower image, the narrow blue channel just below the red arrow is the fish bypass (images provided by MMI Engineering courtesy of the Penobscot River Restoration Trust).

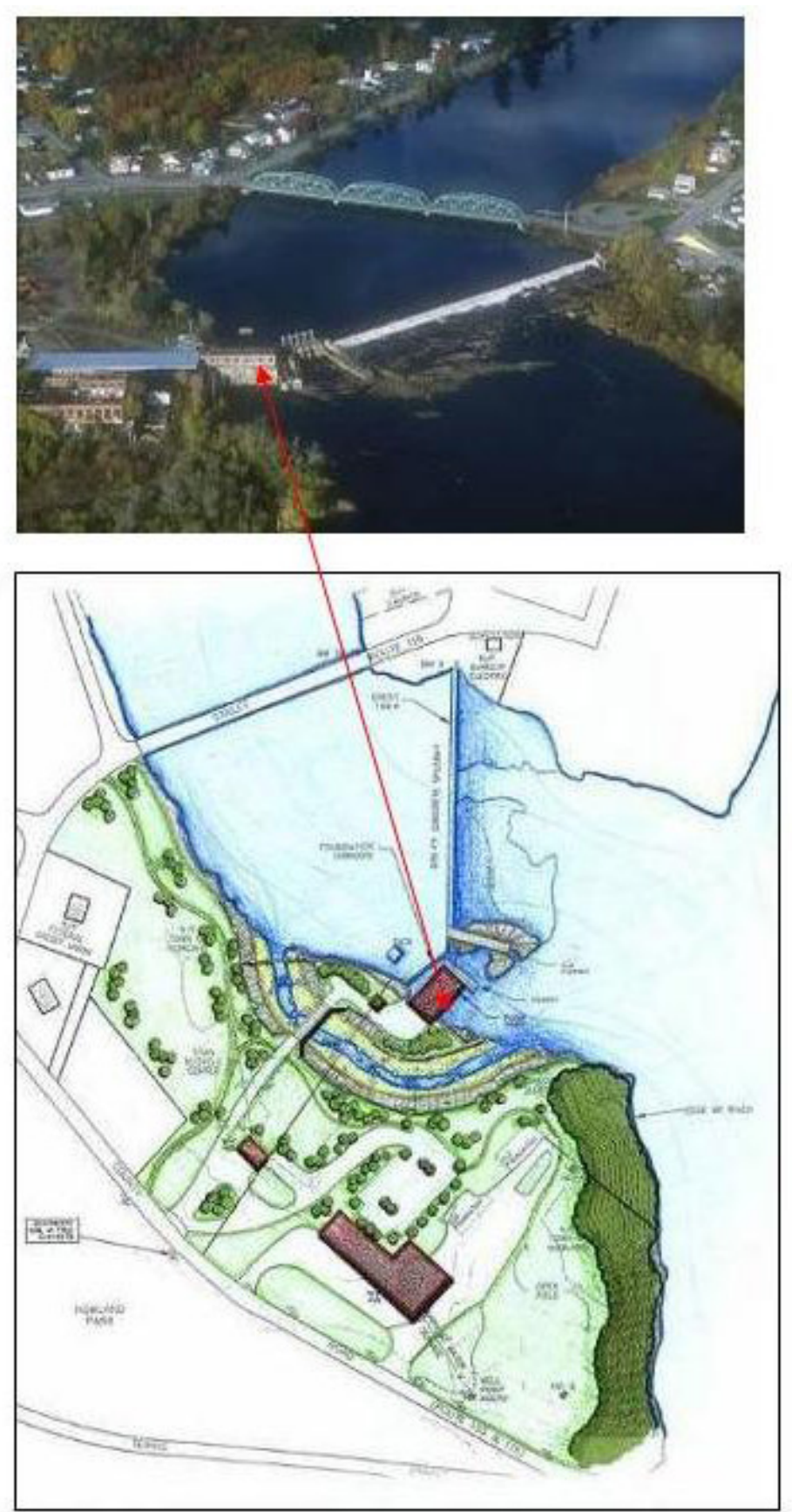


Fig. 4. Total annual energy production before and after Project completion. Dams with "warm" colors in the "before" column will be removed and are not repeated in the "after" column. Note that several dams have greater energy production after the Project.

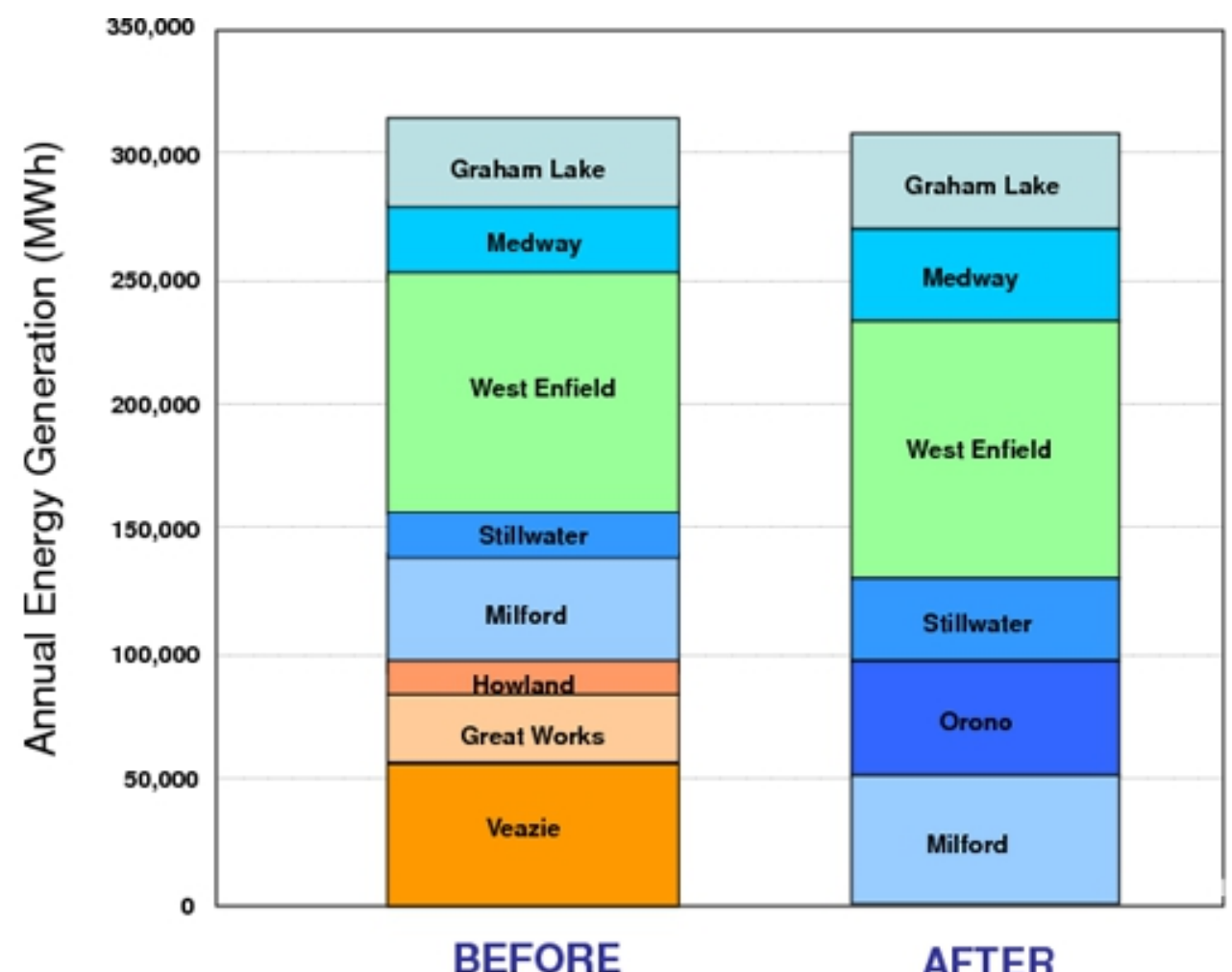

Conservative projections estimate that following Project completion, accessible habitat will increase to approximately $6900 \mathrm{~km}$ (Table 1 , Fig. 5). This estimate is conservative because it does not include much of the watershed's tributaries that can potentially provide salmon habitat but have not been surveyed or mapped.

The increase in free-flowing riverine habitat and connectivity throughout the basin are projected to promote dramatic increases in the populations of migratory fish species (Table 3). For example, fisheries biologists estimate that American shad will increase from a few hundred today to approximately 2 million and Atlantic salmon to increase from approximately 2000 to 12,000 (National Research Council 2004, Maine Department of Marine Resources 2009).

When fully implemented, the Project is expected to contribute to the recovery of populations of migratory fish that historically spawned and reared in the Penobscot. For PPL Corporation, the agreement provides business certainty and equivalent energy production and no jobs will be lost as a result of the Project. The estimated overall cost of purchasing the Veazie, Great Works, and Howland dams, removing the two lowermost dams and bypassing Howland, and associated implementation costs is approximately US\$55 million. By late 2007 the Trust and its partners had raised, from a combination of federal and private sources, US\$25 million to buy the dams and purchased them in December 2010. The Trust has received all necessary state and federal permits and full project implementation will begin when the Trust raises the funds to remove Veazie Dam and construct the Howland Bypass. 
Fig. 5. Fish passage scenarios before and after the Penobscot River Restoration Project. Reaches and tributaries are color-coded to represent how many dams lie between them and the ocean. A key feature of the Project is providing state-of-the-art fish passage at the mainstem dams that will remain after project completion.

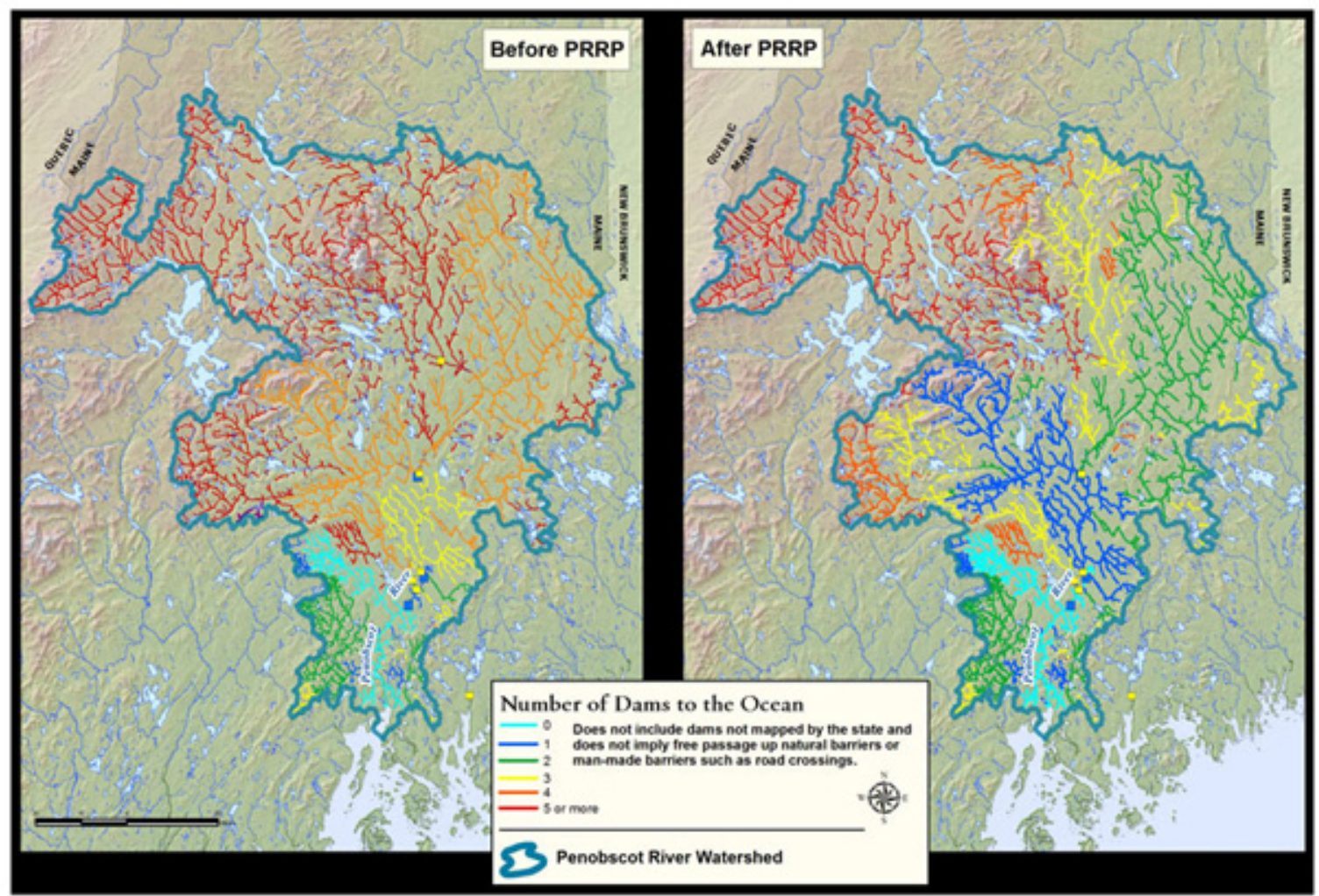

\section{CULTURAL AND ECONOMIC IMPLICATIONS OF THE PROJECT}

The Penobscot Indian Nation's cultural history, as expressed through legends, customs, and historical narratives, emphasizes its relationship to the river and their role as stewards of the basin's inhabitants and resources. Today, many tribal members continue to view the river as a sacred, living entity that is central to the Tribe's cultural identity. The resources of the Penobscot River watershed have supported the tribe for thousands of years, providing food, medicines, and materials for making tools, appliances, shelter, and weapons. Because they view the river and its resources as a gift from the Creator, many members of the Tribe see the Project as an act of reciprocity that contributes to the partial restoration of historic conditions and resources. For more than a century the Penobscot have not been able to exercise their sovereign fishing rights because virtually no migratory fish of value to the Tribe make it beyond the dams downstream of their reservation.

In addition to the restoration of economically and culturally significant resources for the Tribe, the Project is expected to have a net positive economic benefit on Penobscot County, a region with a median income in 2000 almost $20 \%$ below the national average (FERC 2010). Direct economic benefits of the project are estimated to include almost 200 short-term construction jobs, adding approximately US\$8 million to the local economy (FERC 2010). The Project's potential long-term benefits associated with increasing the extent of free-flowing river, including boating, wildlife viewing, and commercial and recreational fishing, were demonstrated following dam removal on the 
Table 3. Expected changes in fish populations in the Penobscot River from the Project by 2020.

\begin{tabular}{lcc}
\hline \hline & \multicolumn{2}{c}{ Population } \\
\cline { 2 - 3 } & Current & Expected Future \\
\hline $\begin{array}{l}\text { Alewife } \\
\text { (Alosa pseudoharengus) }\end{array}$ & 2000 & $4,500,000$ \\
$\begin{array}{l}\text { Atlantic salmon } \\
\text { (Salmo salar) }\end{array}$ & 2000 & 12,000 \\
$\begin{array}{l}\text { American Shad } \\
\text { (Alosa sapidissima) }\end{array}$ & hundreds & $2,000,000$ \\
\hline
\end{tabular}

neighboring Kennebec and Sebasticook Rivers (Crane 2009). Further, several of the Penobscot's migratory fish species historically provided an important food source for cod and other marine groundfish, populations of which are currently greatly depressed in the Gulf of Maine. Thus the projected population increases in migratory fish following dam removal may benefit the economically and culturally important commercial and recreational marine fisheries in the Gulf (Ames 2004).

\section{INSIGHTS FROM THE PENOBSCOT FOR SUSTAINABLE HYDROPOWER}

The Penobscot River Restoration Project features two primary projected outcomes: a dramatic, ecologically significant increase in the proportion of the basin accessible to migratory fish (Fig. 5, Table 1), combined with a slight increase in energy generation (Fig. 4). Although many conditions and previous events facilitated these outcomes, the geographic scope of the project, a large proportion of the basin, was critically important. The Penobscot provides one of the few examples of such a basinscale approach to improving the sustainability of hydropower and it illustrates many of the key advantages of this large spatial scale. The basin scale greatly expanded the set of possible solutions for both energy and water and increased the incremental improvement in hydropower sustainability (Fig. 6).

Although the sustainability of individual projects can be improved, providing important environmental benefits (Richter and Thomas 2007), solutions focused on a single site are more likely to encounter zero-sum constraints, i.e., substantial gains for either energy production or environmental protection come at the expense of the other. In contrast, the multidam, basin-scale approach allowed for significant environmental gains to come at no cost in terms of lost energy production.

The Project encompassed built infrastructure in a mature regulatory context and its basin-scale approach was facilitated by single ownership of all dams involved, a strong regulatory incentive (fishpassage license conditions) and a clear and measurable environmental performance metric (fish passage and fish populations). Although these specific factors may seem to limit the replicability of the Project's approach and outcomes, we provide recommendations for how such outcomes can be replicated more widely and discuss the conceptual insights from the Project for the planning of future dams in regions undergoing expansion of watermanagement infrastructure.

Although we use the term 'basin scale' to describe the Penobscot, it should be noted that the Project did not address all hydropower dams nor all environmental issues in the basin. The Project did address all the lower main stem hydropower dams that affect basin-wide connectivity, and the geographic scope of the environmental benefits approaches that of the entire basin. However, we do not realistically expect that basin-scale approaches will capture all dams or environmental issues within a basin and we emphasize the insights provided by 
Fig. 6. A conceptual diagram of the relative potential for improving the sustainability of hydropower projects at various spatial scales and stages of development. The y-axis represents the potential incremental improvement in environmental sustainability for a given energy generation target. The greatest potential improvement occurs during initial site selection and the potential for improvement is lowest once a project is already constructed. A regional or basin-scale approach (solid line) provides a greater set of potential solutions, and thus greater potential sustainability, than a single-project approach. By adopting a basin-scale approach, the Penobscot Project moved from position "a" to position "b" on this conceptual diagram.

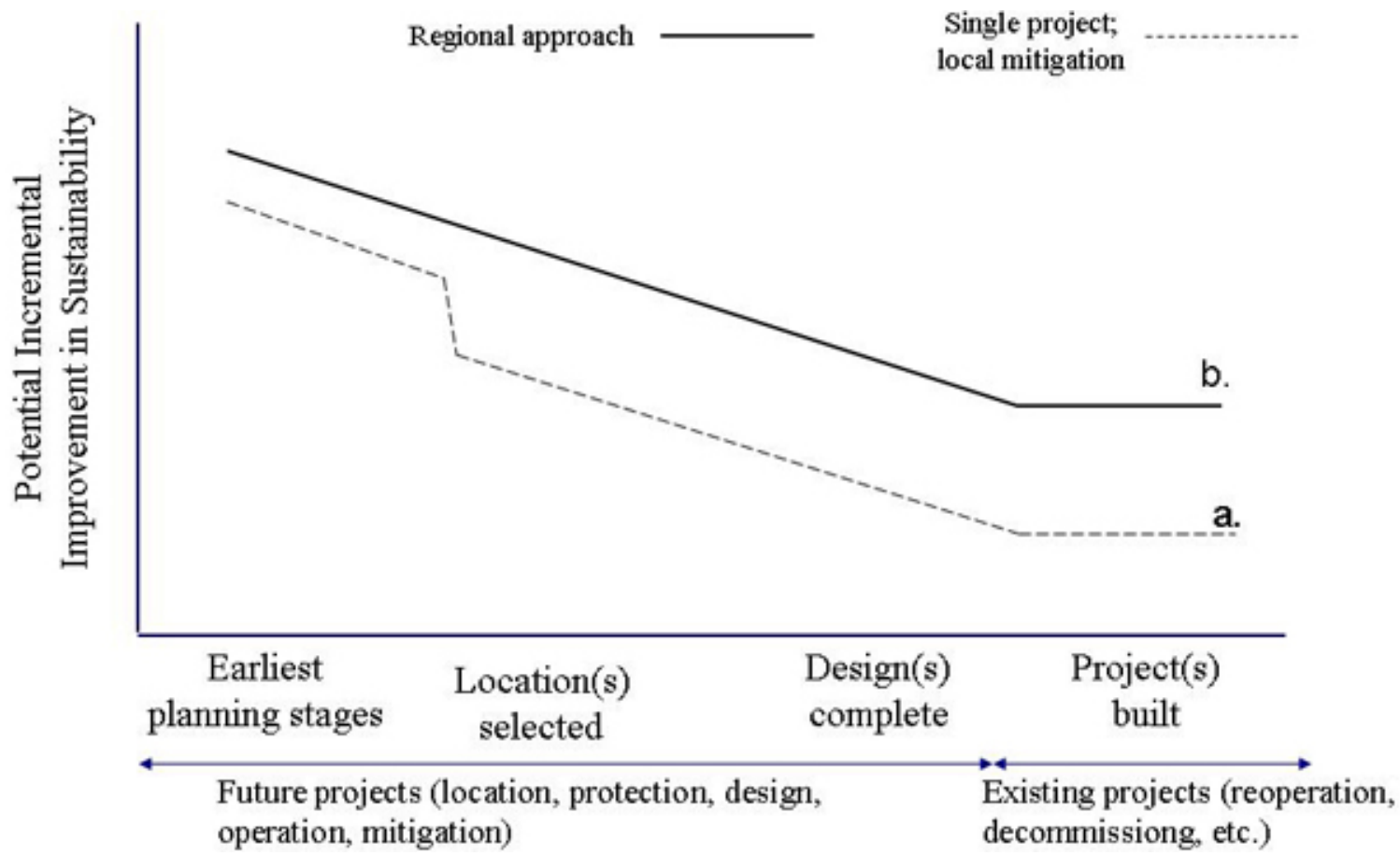

a hydropower project that addressed basin-scale problems and solutions to the greatest extent practicable.

\section{Insights for the licensing of hydropower dams}

The Project most directly demonstrates the innovative solutions possible through FERC licensing processes focused at a basin scale. FERC does not currently require coordinated review and licensing of projects within a basin, although FERC will allow the bundling of projects with different license dates to promote basin-scale licensing. Innovative outcomes within licensing processes, such as occurred in the Penobscot, are made possible by FERC's willingness to allow unconventional licensing processes to occur, provided they can be reconciled with regulatory requirements. Although we emphasize the benefits afforded by basin-scale, multidam approaches that can potentially achieve positive outcomes for both energy capacity and environmental health, we do not intend to minimize the potential benefits of single-dam licensing processes nor mean to imply that all river restoration projects must achieve energy neutrality. For example, the removal of Edwards Dam on the Kennebec River produced impressive restoration of fish habitat and FERC deemed that the environmental benefits outweighed the loss of energy. However, because multidam or basin-scale approaches to licensing have great potential to result in innovative solutions for balancing energy production and river ecosystem health, we recommend three approaches for pursuing basinscale FERC relicensing to increase the frequency of such outcomes. 
First, as happened in the Penobscot, licensees, agencies, and stakeholders can agree to work together at multiple dams and across large spatial scales and FERC can accommodate the coordinated review and licensing of projects with different license expiration dates. This coordinated, basinscale approach can achieve a range of solutions that may be difficult or impossible to achieve at the scale of a single project. This approach requires flexibility, innovation, and collaboration among parties. Although some coordinated review is triggered by possibly contentious license conditions, such as fish passage, we suggest that licensees and stakeholders pursue coordinated approaches even in situations lacking conflict. Further, FERC could incentivize the coordinated licensing of projects through policies that streamlined environmental review under the National Environmental Policy Act (NEPA) for all projects within a coordinated relicensing.

Second, under NEPA, Federal agencies have a duty to fully consider cumulative impacts. Although FERC generally requires a description of cumulative impacts within license applications, they only require mitigation for direct impacts and consider cumulative impacts essentially unmitigable (Hydropower Reform Coalition 2005). If FERC required that greater attention be paid to cumulative impacts and potential mitigation for those impacts, the Commission could greatly increase licensees' incentives to pursue coordinated, basin-scale review and relicensing, even across multiple ownerships.

Finally, Section 10(a) of the FPA requires FERC to ensure that hydropower projects are consistent with basin-scale plans (Echeverria et al. 1989). Section 10(a)(1) requires that FERC review license applications in the context of a "comprehensive plan" for the basin that considers and balances a full range of resources. Although environmental interests have suggested that this requires FERC to develop its own basin plans, the Commission has maintained that it can determine a project's consistency with a comprehensive plan based on the information contained within a project's application (Echeverria et al. 1989).

Section 10(a)(2), added through ECPA, provides additional direction to FERC that it needs to evaluate projects within a basin context. The Section requires FERC to consider whether a project is consistent with a comprehensive plan for a river basin developed by other state or federal agencies (Gillilan and Brown 1997). If state and/or federal resource agencies and other stakeholders developed a comprehensive plan for achieving energy production and environmental restoration objectives within a basin, in theory FERC should therefore ensure that relicensing processes and outcomes are consistent with that comprehensive basin plan. In practice, however, FERC generally concludes that project licenses are consistent with any relevant comprehensive plan without elaboration on the basis for this finding.

Although both provisions for project consistency with basin-scale comprehensive plans are currently underutilized, Section 10(a) provides the policy foundation for moving licensing toward the basin scale. Achieving this potential may require additional resources or policy guidance for FERC.

\section{Insights for basin-scale planning and management of new hydropower projects}

Beyond the insights for FERC relicensing, which apply specifically to the regulatory context of hydropower operations within the U.S., the Penobscot illustrates more generally the benefits of integrated, basin-scale management of environmental resources and infrastructure. This scale of management is widely recommended and articulated within concepts such as Integrated Water Resources Management (IWRM) and Integrated River Basin Management (IRBM). A key lesson from the Project is that a basin-scale approach to balancing energy production and environmental protection can draw from a broader set of solutions than is available to single-project-scale processes. Although the Penobscot River Restoration Project is most directly relevant for basins confronting the challenge of improving the environmental sustainability of existing infrastructure, its geographic scale and set of solutions also provide insight for how hydropower can be developed more sustainably.

Driven by growing demand for energy, hydropower dams are now being rapidly built in river basins in Asia, Africa, and Latin America. The river basins facing a proliferation of new hydropower dams often support both high levels of biodiversity and large human populations that depend upon fisheries or agriculture maintained by free-flowing riverfloodplain processes (Dudgeon 2000, Richter et al. 
2010). The environmental and social impacts of hydropower projects have been described thoroughly elsewhere (World Commission on Dams 2000, Postel and Richter 2003) so we simply note that hydropower dams can dramatically alter the ecological health of rivers and degrade ecosystem services dependent on free-flowing river systems. As hydropower expands into basins with relatively unaltered hydrology, planners are seeking solutions to minimize dam impacts and achieve greater sustainability than in previous eras of rapid expansion (Ledec and Quintero 2003, IHA 2004, 2006, Richter et al. 2010).

Of the primary impacts caused by dams, only a few can be mitigated, and often only partially, at the scale of a single dam, with the effectiveness of mitigation varying with the size of the dam and its reservoir. For example, although fish passage can be effective for certain species, e.g., salmon, with certain dam heights and other conditions, for many other species and/or dam configurations, fish passage infrastructure is ineffective or impracticable (Pelicice and Agostinho 2008). Dams can release environmental flows, but the benefits can be constrained by the size or level of the outlet or by objectives for energy. Because of the limitations of project-level mitigation, a World Bank report concluded that the most effective form of "mitigation" is site selection (Ledec and Quintero 2003), i.e., avoiding or minimizing impacts through dam location rather than through mitigation after construction (Fig. 6).

Beyond site selection, achieving more sustainable hydropower in regions undergoing expansion of infrastructure will require integrated, basin-scale approaches to energy and water infrastructure planning and development (World Commission on Dams 2000). Such approaches seek to meet energy generation objectives while minimizing environmental impacts and to achieve a balance between the benefits provided by regulated rivers, e.g., energy and water supply, and those provided by unregulated rivers, e.g., fisheries and biodiversity (Harrison et al. 2007). The basic components and principles of this approach include:

1. Develop realistic forecasts of energy demand and an assessment of alternatives for meeting that demand; options should not be limited to hydropower but include other forms of energy generation, energy conservation, and efficiency. From this forecast and options assessment, resolve a hydropower energy target and develop a process for planning, siting, and reviewing individual projects within a framework that integrates data and objectives for hydropower with those for conservation of environmental and social resources;

2. Avoid dam construction in locations that will have the greatest environmental and social impacts or have impacts that cannot be effectively mitigated;

3. Incorporate effective site-specific mitigation strategies, such as fish passage and environmental flows, where new dams will impact important resources;

4. Direct dam development to locations with the lowest impacts and, potentially, relax the environmental constraints on such dams;

5. Develop integrated mitigation, monitoring, and adaptive management programs;

6. Coordinate planning among sectors, e.g., water, flood control, and energy, and between planned and existing infrastructure at geographic scales beyond the basin to capture relevant economic scales, e.g., an energy grid.

Although the dams on the Penobscot are more than a century old, the Project illustrates several of the above principles for sustainable planning and development of future hydropower development. The Project will result in the removal of the dams with the greatest environmental impacts and for which project-scale mitigation had been ineffective at addressing environmental impacts. This is analogous to an integrated, basin-scale planning process in which new dams avoid the most environmentally vulnerable locations (principle 2). Where dams on the Penobscot will remain and that are associated with potentially high environmental impacts, state-of-the-art mitigation techniques, in this case, fish passage, will be deployed, corresponding to the third principle. Energy capacity will be increased and expensive mitigation not required for dams that, because of their location on a side channel, have the lowest environmental impacts, corresponding to the fourth principle. The Project includes a monitoring program to inform adaptive management based on ecological responses (principle 5).

The Project also includes some parallels to the sixth principle. For example, the Settlement Accord includes permission to increase energy capacity at 
one PPL dam outside of the Penobscot basin, thus working within an economic geographic scale that exceeds the basin. Further, the decision for dam removal occurred as additional renewable energy, in the form of wind power, was entering Maine's power portfolio, illustrating that contributions from other sectors can facilitate sustainable hydropower solutions.

A final observation from the Penobscot case is that more balanced solutions between hydropower and environmental resources will almost certainly require less than complete utilization of a basin's hydropower potential. Although generation will be maintained or slightly increased from the Penobscot, greater hydropower generation would have been possible through operational changes or capacity or efficiency upgrades at all of the dams, i.e., including those that will be decommissioned under the Project. Because the "energy generation goal" for the Penobscot represents less than complete utilization of basin potential, the Project was able to strike a balance between hydropower and other river values.

Moreover, the Project represents the ultimate objectives of sustainable hydropower planning and development: the attainment of an energy generation goal with the lowest possible environmental impacts. With the caveat that the Project addresses built infrastructure, it illustrates how an integrated, basin-scale approach to hydropower planning can reveal that a given energy target can be achieved through alternatives with very different environmental impacts.

In the Penobscot, the two alternatives are: (1) the original configuration and design of dams; and (2) the configuration and design of dams after Project completion. These two alternatives have nearly equivalent energy values (Fig. 4) but the latter alternative has significantly lower environmental and social costs and comes closer to retaining a largely functional river system (Table 3, Fig. 5). Although relatively simple compared to the complex planning challenges faced by many basins, in particular those in water scarce, less-developed nations where the conflicts between water, energy, and food production are more dire, the lessons of the Penobscot for basin-scale planning for sustainable hydropower are clear: seek alternatives that achieve the greatest balance of energy production and environmental health and implement those alternatives the first time, not after a century of environmental and social impacts.

Responses to this article can be read online at: http://www.ecologyandsociety.org/voll6/iss3/art7/responses/

\section{Acknowledgments:}

H. Locher, N. Silk, J. Pittock, K. Hussey, and J. Seebach provided very helpful reviews that improved this paper.

\section{LITERATURE CITED}

Ames, E. P. 2004. Atlantic Cod stock structure in the Gulf of Maine. Fisheries 29(1):10-28.

Atkins, C. G., and N. W. Foster. 1869. Report of Commission of Fisheries. Commissioners of Fisheries, Augusta, Maine, USA. [online] URL: http://www.kennebecriverartisans.com/kennebec.org/ fks/penobatkins.html

Bowman, M. B. 2002. Legal perspectives on dam removal. Bioscience 52(8):739-747. http://dx.doi.o $\mathrm{rg} / 10.1641 / 0006-3568(2002) 052[0739$ :LPODR]2.0. $\mathrm{CO} ; 2$

Bunn, S. E., and A. H. Arthington. 2002. Basic principles and ecological consequences of altered flow regimes for aquatic biodiversity. Environmental Management 30(4):492-507. http://dx.doi.org/10.1 $\underline{007 / s 00267-002-2737-0}$

Crane, J. 2009. "Setting the river free": the removal of the Edwards Dam and the restoration of the Kennebec River. Water History 1:131-148 http://dx .doi.org/10.1007/s12685-009-0007-2

Dudgeon, D. 2000. Large-scale hydrological changes in tropical Asia: prospects for riverine biodiversity. Bioscience 50:793-806. http://dx.doi.o $\mathrm{rg} / 10.1641 / 0006-3568(2000) 050[0793:$ LSHCIT]2.0. $\mathrm{CO} ; 2$

Echeverria, J. D., P. Barrow, and R. Roos-Collins. 1989. Rivers at risk: a concerned citizen's guide to hydropower. Island Press, Washington, D.C., USA. 
Federal Energy Regulatory Commission (FERC). 1997. Final environmental impact statement licensing three hydroelectric projects in the Lower Penobscot River Basin. FERC Project Nos. 2403-056, 2312-019 and 2721-020. FERC, Washington, D.C., USA.

Federal Energy Regulatory Commission (FERC). 2004. Submittal of the Lower Penobscot River Basin comprehensive settlement accord with explanatory statement. Project Nos. 2403, 2534, 2666, 2710, 2712, 2721, and 10981. Federal Register, Docket No. DI97-10. FERC, Washington, D.C., USA.

Federal Energy Regulatory Commission (FERC). 2010. Final environmental assessment, application for surrender of license, Veazie, Great Works and Howland Projects Nos. 2403-056, 2312-019, and 2721-020. FERC, Washington, D.C., USA.

Gillilan, D. M., and T. C. Brown. 1997. Instream flow protection: seeking a balance in Western water use. Island Press, Washington, D.C., USA.

Harrison, D., J. J. Opperman, and B. Richter. 2007. Can hydro power be sustainable? Water Power \& Dam Construction 59(10):22-25.

Hydropower Reform Coalition. 2005. Citizen toolkit for effective participation in hydropower relicensing. Hydropower Reform Coalition, Washington, D.C., USA. [online] URL: http://www .hydroreform.org/hydroguide/hydropower-licensing/ citizen-toolkit-for-effective-participation

International Hydropower Association (IHA). 2004. Sustainability guidelines. London, UK. [online] URL: http://www.hydropower.org/downloads/ IHA\%20Sustainability\%20Guidelines Feb04.pdf

International Hydropower Association (IHA). 2006. Sustainability assessment protocol. London, UK. [online] URL: http://www.hydropower.org/do wnloads/IHA SAP.pdf.

Ledec, G., and J. D. Quintero. 2003. Good dams and bad dams: environmental criteria for site selection of hydroelectric projects. The World Bank, Washington, D.C., USA.

Ligon, F. K., W. E. Dietrich, and W. J. Trush. 1995. Downstream ecological effects of dams. Bioscience 45(3):183-191. http://dx.doi.org/10.2307/1312557
Maine Department of Marine Resources and Maine Department of Inland Fisheries. 2009. Operational plan for the restoration of diadromous fishes to the Penobscot River. Maine Department of Marine Resources and Maine Department of Inland Fisheries, Augusta, Maine, USA. [online] URL: http://www.penobscotriver.org/assets/

DMR Operational Plan Part 3 of 3 inlcudes $M$ $\underline{\mathrm{OU}}$ at end - reduced file size.pdf

Montgomery, D. R. 2003. King of fish: the thousand-year run of salmon. Westview, Boulder, Colorado, USA.

National Oceanic and Atmospheric Administration (NOAA). 1998. Climatological data, annual summary, New England. NOAA, Washington, D. C., USA.

National Oceanic and Atmospheric Administration (NOAA). 2009. Final rule to list the expanded Gulf of Maine DPS as endangered under the ESA. NOAA, Washington, D.C., USA.

National Research Council (NRC). 2004. Atlantic Salmon in Maine. National Academies Press, Washington, D.C., USA.

Pelicice, F. M., and A. A. Agostinho. 2008. Fishpassage facilities as ecological traps in large neotropical rivers. Conservation Biology 22 (1):180-188. http://dx.doi.org/10.1111/j.1523-1739 $.2007 .00849 . \mathrm{x}$

Penobscot Department of Natural Resources. 2001. The Penobscot Nation and the Penobscot River Basin: a watershed analysis and management pilot project. Penobscot Department of Natural Resources, Indian Island, Maine, USA.

Pollak, D. 2007. S. D. Warren and the erosion of federal preeminence in hydropower regulation. Ecology Law Quarterly 34(3):763-800.

Postel, S., and B. Richter. 2003. Rivers for life: managing water for people and nature. Island Press, Washington, D.C., USA.

Richter B. D., S. Postel, C. Revenga, T. Scudder, B. Lehner, A Churchill, and M. Chow. 2010. Lost in development's shadow: the downstream human consequences of dams. Water Alternatives 3 (2):14-42. 
Richter, B. D., and G. A. Thomas. 2007. Restoring environmental flows by modifying dam operations. Ecology and Society 12(1): 12. [online] URL: http: //www.ecologyandsociety.org/vol12/iss1/art12/

Robinson, B. S., G. L. Jacobson, M. G. Yates, A. E. Spiess, and E. R. Cowie. 2009. Atlantic salmon, archaeology, and climate change in New England. Journal of Archaeological Science 36(10):2184-2191. http://dx.doi.org/10.1016/j.jas.2009.06.001

Sanger, D., W. R. Belcher, and D. C. Kellog. 1992. Early Holocene occupation at the Blackman Stream Site, central Maine. Pages 149-162 in B. S. Robinson, J. B. Petersen, and A. K. Robinson, editors. Early Holocene occupation in Northern New England. Maine Historic Preservation Commission, Augusta, Maine, USA.

Saunders, R., M. A. Hachey, and C. W. Fay. 2006. Maine's diadromous fish community: past, present, and implications for Atlantic salmon recovery. Fisheries 31(11):537-547. http://dx.doi.org/10.157 7/1548-8446(2006)31[537:MDFC]2.0.CO;2

Williams, Chase \& Co. 1882. History of Penobscot County, Maine. Williams, Chase \& Co., Cleveland, Ohio, USA. [online] URL: http://www.archive.org/ details/historyofpenobsc00will

World Commission on Dams. 2000. Dams and development: a new framework for decisionmaking. Earthscan, London, UK. [online] URL: ht tp://hqweb.unep.org/dams/WCD/report/WCD DAMS\% 20report.pdf 